\title{
NOTES ON AUSTRALASIAN ORCHIDACEAE 7: UPDATES ON THE NOMENCLATURE OF SULLIVANIA (DIURIDEAE: DRAKAEINAE)
}

\author{
Mark A. Clements ${ }^{1,2,4} \&$ David L. Jones ${ }^{3}$ \\ ${ }^{1}$ Australian National Herbarium/Centre for Australian National Biodiversity Research, CSIRO Plant \\ Industry GPO Box 1700 Canberra, ACT 2601, Australia \\ ${ }^{2}$ Australian National Botanic Gardens, GPO Box 1777 Canberra, ACT 2601, Australia \\ ${ }^{3}$ Kalaru, New South Wales 2550, Australia \\ ${ }^{4}$ Author for correspondence: mark.clements@csiro.au
}

\begin{abstract}
Sullivania F.Muell. (Orchidaceae) is recognised as a validly published genus having priority over Paracaleana Blaxell, and thirteen species (eleven described) in Paracaleana are here transferred to it.

Key words/Palabras Clave: Australia, Caleana, Caleya, flora, nomenclatural adjustments, ajustes nomenclaturales, orchid, orquídea, Paracaleana
\end{abstract}

Introduction. Sullivania F.Muell. and Caleana R.Br. are sister genera within the subtribe Drakaeinae and molecular studies have confirmed their close ancestral relationship (Miller \& Clements 2014, Peakall et al. 2021). Differences in their morphology (Blaxell 1972) and pollination syndromes (Cady 1965, Bower 2014) support their status as distinct genera. The same molecular studies also confirm that within Sullivania there are two distinct groups of species, those with narrowly linear leaves and those with ovate to ovatelanceolate leaves. These two groups were formally recognised respectively as subgenera: Sullivania subg. Sullivania and Sullivania subg. Tanychila (D.L.Jones \& M.A.Clem.) D.L.Jones \& M.A.Clem. (Jones et al. 2002, Jones \& Clements 2005).

There has been debate about the use of the generic name Sullivania as compared to Paracaleana Blaxell (Hopper \& Brown 2006). In the Australian Plant Name Index (APNI 2021) the following definitive statement is provided about the status of the genus Sullivania: Mueller cites this name as "Sullivania, F. v. Mueller, inedited" and provides a brief diagnosis. This was interpreted by Hopper \& Brown, Austral. Syst. Bot. 19(3): 215 (2006), as being a provisional name and thus not validly published. However, as Mueller provided the place of publication for all other generic names in this work, his use of "inedited" is here interpreted as an indication that the name had not been previously published. The diagnosis provided is sufficient for valid publication of the name under ICN Art.38.1 (Shenzhen Code, 2018). The key interpretation here for validity of the name is the interpretation of 'inedited', which appears to indicate simply that the name was previously unpublished by Mueller, rather than an expression of taxonomic non-acceptance by Mueller. This is consistent with other usage of the word by Mueller.

On this basis, Sullivania (Mueller 1882) is the earliest validly published generic name available for the group of species included by some authors under the name Paracaleana (Blaxell 1972). Paracaleana is therefore considered a taxonomic synonym of Sullivania as first proposed by Jones and Clements (2005). Those species described in Paracaleana, but lacking combinations in Sullivania, require nomenclatural adjustments to facilitate their recognition and conservation by Federal and State agencies and are therefore transferred to Sullivania in this paper.

\section{TAXONOMIC TREATMENT}

Sullivania F.Muell., J. Proc. Roy. Soc. New South Wales 15: 229 (1882). Type: Caleya sullivanii F.Muell., designated by Jones and Clements (2005).

Paracaleana Blaxell, Contr. New South Wales Natl. Herb. 4: 281(1972). Type: Caleana minor R.Br.

\section{Sullivania subgen. Sullivania \\ Sullivania lyonsii (Hopper \& A.P.Br.) D.L.Jones \& M.A.Clem., comb. nov.}




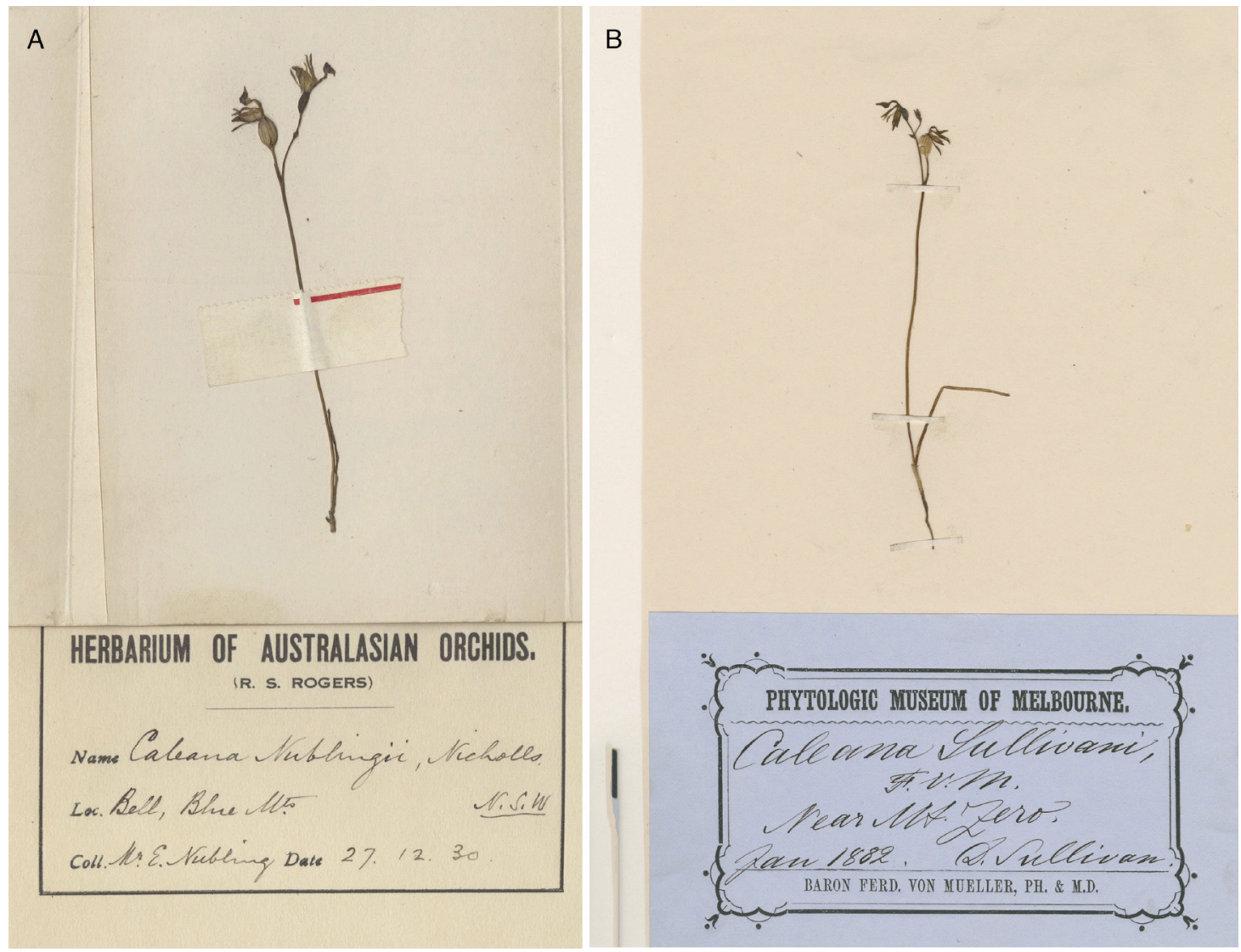

FIgure 1. A. Caleana nublingii (= Sullivania nublingii), syntype (AD 966090281). B. Caleya sullivanii (= Sullivania sullivanii), holotype (MEL 39741).

Basionym: Paracaleana lyonsii Hopper \& A.P.Br., Aust. Syst. Bot.19(3): 219-221, Figs 4, 5 (map) (2006). Fig. 2a.

Sullivania minor (R.Br.) D.L.Jones \& M.A.Clem., The Orchadian 15(1): 36 (2005). Fig 2b.

Note: Developmental embryological research on plants of $S$. minor revealed that this species is a facultative apomict (Clements 1995). It is capable of producing seed through sexual or apomictic reproductive means, even in the same capsule. Seed produced through apomixis facilitates the production of potential new plants, even in the absence of suitable pollinators. Apomixis can also lead to the development, and possible continuance, of mutational forms, and it is thought both $S$. nublingii and $S$. sullivanii originated in this manner. Of the two, $S$. nublingii is the rarest - a small population having been found only once, in the Blue Mountains, New South Wales. However, S. sullivanii occurs in two main populations, approximately $400 \mathrm{~km}$ apart, one in the Grampians, Victoria and the second in the Mt Lofty Ranges, South Australia.

Sullivania nublingii (Nicholls) D.L.Jones \& M.A.Clem., comb. nov.

Basionym: Caleana nublingii Nicholls, Victorian Naturalist 48(1): 15, 17, plate (1931). Fig. 1a.

Sullivania sullivanii (F.Muell.) D.L.Jones \& M.A.Clem., comb. nov.

Basionym: Caleya sullivanii F.Muell., Chem. \& Druggist, Austral. Suppl. 4(45): 68-69 (1882). Fig. 1 b.

Sullivania subgen. Tanychila (D.L.Jones \& M.A.Clem.) D.L.Jones \& M.A.Clem., The Orchadian 15(1): 36 (2005). 

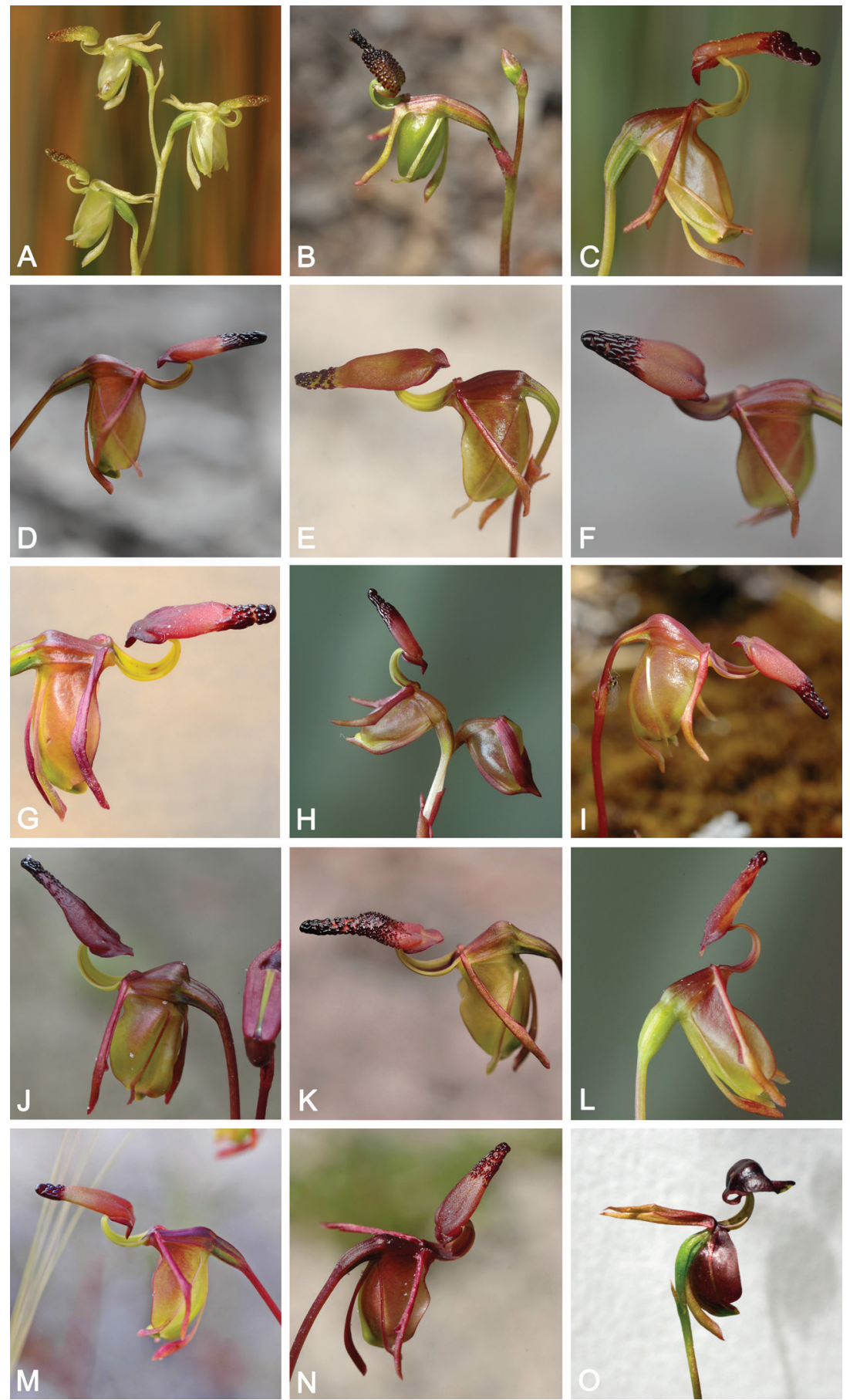

Figure 2. A. Sullivania lyonsii. B. Sullivania minor*. C. Sullivania alcockii. D. Sullivania brockmanii. E. Sullivania dixonii. F. Sullivania disjuncta*. G. Sullivania ferricola. H. Sullivania gracilicordata. I. Sullivania granitica. J. Sullivania hortiorum. K. Sullivania nigrita*. L. Sullivania parvula. M. Sullivania terminalis. N. Sullivania triens. O. Caleana major. All photos by G. Brockman except (B) and (O) by Z.Groeneveld. * indicates species previously transferred to Sullivania but included here for completeness. 
Type species: Paracaleana nigrita (J.Drummond ex Lindl.) Blaxell

Sullivania alcockii (Hopper \& A.P.Br.) D.L.Jones \& M.A.Clem., comb. nov.

Basionym: Paracaleana alcockii Hopper \& A.P.Br., Aust. Syst. Bot.19(3): 222-223, Fig. 2, 6, 7 (map) (2006). Fig. 2c.

Sullivania brockmanii (Hopper \& A.P.Br.) D.L.Jones \& M.A.Clem., comb. nov.

Basionym: Paracaleana brockmanii Hopper \& A.P.Br., Aust. Syst. Bot.19(3): 223-225, Figs 2, 8, 9 (map) (2006). Fig $2 d$.

Sullivania disjuncta (D.L.Jones) D.L.Jones \& M.A.Clem., The Orchadian 15(1): 36 (2005). Fig 2 f.

Sullivania dixonii (Hopper \& A.P.Br.) D.L.Jones \& M.A.Clem., comb. nov.

Basionym: Paracaleana dixonii Hopper \& A.P.Br., Aust. Syst. Bot.19(3): 228-229, Figs 2, 12, 13 (map) (2006). Fig 2e.

Sullivania ferricola (A.P.Br. \& G.Brockman) D.L.Jones \& M.A.Clem., comb. nov.

Basionym: Paracaleana ferricola A.P.Br. \& G.Brockman, Nuytsia 30: 287-289, Fig. 1 (2019). Fig 2g.

Sullivania gracilicordata (Hopper \& A.P.Br.) D.L.Jones \& M.A.Clem., comb. nov.

Basionym: Paracaleana gracilicordata Hopper \& A.P.Br., Aust. Syst. Bot.19(3): 229-230, f.2, 14, 15 (map) (2006). Fig $2 \mathrm{~h}$.

Sullivania granitica (Hopper \& A.P.Br.) D.L.Jones \& M.A.Clem., comb. nov.
Basionym: Paracaleana granitica Hopper \& A.P.Br., Aust. Syst. Bot.19(3): 230-232, Figs 2, 16, 17 (map) (2006). Fig $2 \mathrm{i}$.

Sullivania hortiorum (Hopper \& A.P.Br.) D.L.Jones \& M.A.Clem., comb. nov.

Basionym: Paracaleana hortiorum Hopper \& A.P.Br., Aust. Syst. Bot.19(3): 232-234, Figs 2, 18, 19 (map) (2006). Fig $2 \mathrm{j}$.

Sullivania nigrita (J.Drummond ex Lindl.) D.L.Jones \& M.A.Clem., The Orchadian 15(1): 36 (2005). Fig 2k.

Sullivania parvula (Hopper \& A.P.Br.) D.L.Jones \& M.A.Clem., comb. nov.

Basionym: Paracaleana parvula Hopper \& A.P.Br., Aust. Syst. Bot.19(3): 237-238, Figs 2, 23, 24 (map) (2006). Fig 21.

Sullivania terminalis (Hopper \& A.P.Br.) D.L.Jones \& M.A.Clem., comb. nov.

Basionym: Paracaleana terminalis Hopper \& A.P.Br., Aust. Syst. Bot.19(3): 239-240, Figs 2, 25, 26 (map) (2006). Fig $2 \mathrm{~m}$.

Sullivania triens (Hopper \& A.P.Br.) D.L.Jones \& M.A.Clem., comb. nov.

Basionym: Paracaleana triens Hopper \& A.P.Br., Aust. Syst. Bot.19(3): 240-242, Figs 2, 27, 28 (map) (2006). Fig $2 \mathrm{n}$.

ACKNOWLEDGEMENTS. Thanks to Brendan Lepschi and Anna Monro for their nomenclatural expertise, Garry Brockman and Zoe Groeneveld for use of their photos and Heidi Zimmer for critical review of the manuscript.

\section{LiTERATURe Cited}

Australian Plant Name Index (APNI) (2021). IBIS database, Centre for Australian National Biodiversity Research, Australian Government, Canberra. Retrieved from https://biodiversity.org.au/nsl/services/search/names?product=APNI\&tree.

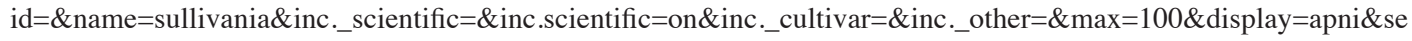
arch=true [Accessed 15 March 2021].

Blaxell, D. F. (1972). Arthrochilus F.Muell. and related genera (Orchidaceae) in Australasia. Contributions from the New South Wales National Herbarium, 4(5), 275-283.

Bower, C. C. (2014). Pollination of the small duck orchid, Paracaleana minor: flower structure and function. The Orchadian, 17(11), 510-515.

Cady, L. (1965). Notes on the pollination of Caleana major R.Br. The Orchadian, 2, 34-5.

Clements, M. A. (1995). Reproductive biology in relation to phylogeny of the Orchidaceae, especially the tribe Diurideae. $\mathrm{PhD}$ Thesis, Australian National University, Canberra.

Hopper, S. D., \& Brown, A. P. (2006). Australia's wasp-pollinated flying duck orchids revised (Paracaleana: Orchidaceae). Australian Systematic Botany, 19(3), 211-244. 
Jones, D. L. \& Clements, M. A. (2005). Miscellaneous nomenclature notes and changes in Australian, New Guinea and New Zealand Orchidaceae. The Orchadian, 15(1), 33-42.

Jones, D. L., Clements, M. A., Sharma, I. K., Mackenzie, A. M. \& Molloy, B. P. J. (2002). Nomenclatural notes arising from studies into the tribe Diurideae (Orchidaceae). The Orchadian, 13(10), 437-68.

Miller, J. T. \& Clements, M. A. (2014). Molecular phylogenetic analysis of Drakaeinae: Diurideae (Orchidaceae) based on DNA sequences of the internal transcribed spacer region. Australian Systematic Botany, 27, 3-22.

Mueller, F. J. H. von (1882). Census of the genera of plants hitherto known as indigenous to Australia. Journal and Proceedings of the Royal Society of New South Wales, 15, 185-300.

Peakall, R., Wong, D. C., Phillips, R. D., Ruibal, M., Eyles, R., Rodríguez-Delgado, C. \& Linde, C. C. (2021). A multitiered sequence capture strategy spanning broad evolutionary scales: Application for phylogenetic and phylogeographic studies of orchids. Molecular Ecology Resources, 21(4), 1118-1140. Doi: https://doi.org/10.1111/1755-0998.13327 
LANKESTERIANA 